\title{
SOSIALISASI PEMASARAN DAN KOMUNIKASI TERHADAP MINAT NASABAH UNTUK MENABUNG DI BMT
}

\author{
Nova Yanti Maleha1), Fadilla2) \\ 1)Program Studi Ekonomi Syariah, STEBIS IGM \\ 2)Program Studi Ketua Prodi Perbankan Syariah, STEBIS IGM \\ Email : nova@stebisigm.ac.id ${ }^{11}$, dilla@stebisigm.ac.id ${ }^{2}$
}

\begin{abstract}
ABSTRAK
Baitul Maal wat Tamwil (BMT) / Koperasi Keuangan Jasa Syariah sebagai lembaga keuangan mikro berbasis syariah muncul dan mencoba menawarkan solusi bagi masyarakat kelas bawah. Oleh karna itu adanya beberapa aspek penting yang harus dilihat dalam keberhasilan BMT yaitu konsep pemberdayaan yang dilakukan BMT sehingga dapat terlihat unggul terutama bagi mahasiswa dan mahasiswi STEBIS IGM dan karakteristik nasabah yang secara otomatis dapat diposisikan sebagai objek pemberdayaan. Pada STEBIS IGM Palembang. Kegiatan ini dimulai dengan pengenalan tentang seputaran jasa BMT (Baitul Maal wat Tamwil) terutama mensosialisasikan bagaimana pemasaran dan kounikasi terhadap nasabah untuk bergabung di BMT. Proses kegiatan dilaksanakan dalam waktu 3 minggu dalam satu bulan mulai dari proses persiapan hingga pembuatan laporan kegiatan. Tujuan kegiatan ini adalah sehingga para mahasiswa/i STEBIS IGM Palembang dapat mengenal produk atau jasa BMT yang dapat meningkatkan pengetahuan dalam menggunakan pembiayaan.
\end{abstract}

Kata kunci : Pemasaran, Komunikasi, Minat Nasabah, dan BMT

\section{PENDAHULUAN}

Ekonomi bagi Islam adalah dalam rangka untuk pemenuhan kebutuhan demi menuju kesejahteraan bersama. Terkait dalam masalah harta meliputi bagaimana suatu aktivitas untuk mendapatkan harta. Adapun aktivitas yang dilaksanakan dapat melalu investasi (baik dengan akad/perjanjian mudharabah/ mudarabah maupun musyarakah), serta melalui jual beli (dengan akad murabahah, ijarah, istishna'/ istisna, dan salam). (Gita Danupranata, 2015)

BMT Merupakan pelaku ekonomi yang lahir dan beroprasi menggunakan akad mengacu pada ekonomi syariah. (Neni Sri Imaniyati, 2010) Lahirnya BMT bertujuan untuk meningkatkan kualitas usaha ekonomi untuk kesejahteraan anggota pada khususnya dan masyarakat pada umumnya. Dan mempunyai sifat, yaitu memiliki usaha bisnis yang bersifat mandiri, ditumbuh kembangkan dengan swadaya dan dikelola secara profesional serta berorientasi untuk kesejahteraan anggota dan masyarakat lingkungan.

Oleh karena itu untuk menyikapi permintaan tersebut perlu adanya tindak lanjut dari organisasi sebagai upaya agar kemampuan pengetahuan mahasiswa lebih meningkat dan minat menabung di BMT lebih tertambah. Salah satunya yaitu dengan adanya Pelatihan dan workshop pemasaran dan komunikasi terhadap minat mahasiswa STEBIS IGM untuk menabung di BMT. Workshop ini telah dilaksanakan pada tanggal 10 Juli 2019. Dengan kegiatan ini diharapkan para mahasiswa STEBIS IGM dapat meningkatkan pengetahuan tentang jasa pemasaran dan komunikasi dalam menabung di BMT.

\subsection{Bentuk Kegiatan}

Kegiatan yang dilakukan adalah Pengenalan bagaimana pemasaran dan komunikasi terhadap minat mahasiswa STEBIS IGM untuk menabung di BMT.

\subsection{Tempat Kegiatan}

Dilaksanakan di STEBIS IGM Jl. Jend. Sudirman KM.4 No.629, 20 Ilir D. IV, Kec. Ilir Tim. I, Kota Palembang, Sumatera Selatan 30129.

\subsection{Waktu Kegiatan dan Materi Pokok dalam Kegiatan}


Pelaksanaan kegiatan dilakukan dalam 1(satu) hari. Adapun jadwal pelaksanaan adalah sebagai berikut:

Tabel 1. Jadwal Pelaksanaan Kegiatan

\begin{tabular}{|c|c|c|}
\hline $\begin{array}{c}\text { Tanggal } \\
\text { Pelaksanaan }\end{array}$ & Waktu & Materi \\
\hline \multirow{2}{*}{ 10 Juli 2019 } & $08: 30-11: 30$ & Workshop Mengenai Bisnis dan Pemasaran \\
\cline { 2 - 3 } & $13: 00-16: 30$ & $\begin{array}{c}\text { Workshop Pengenalan BMT (Baitul Mal Wat } \\
\text { Tanwil) }\end{array}$ \\
\hline
\end{tabular}

\subsection{Durasi Waktu Pelaksanaan Pelatihan}

Durasi waktu yang dibutuhkan selama pembuatan dan pelaksanaan kegiatan pengabdian pada masyarakat tersebut adalah sebagai berikut:

Tabel 2. Durasi Waktu Pembuatan dan Pelaksanaan Kegiatan

\begin{tabular}{|c|c|c|c|}
\hline KEGIATAN & TANGGAL & WAKTU & DURASI \\
\hline $\begin{array}{c}\text { Terima Surat Pemohonan workshop } \\
\text { Mahasiswa dari STEBIS IGM } \\
\text { Palembang ke Ketua STEBIS Indo } \\
\text { Global Mandiri }\end{array}$ & 19 Juni 2019 & $09: 00$ & 1 jam \\
\hline $\begin{array}{c}\text { Rapat koordinasi kegiatan workshop } \\
\text { di STEBIS IGM Palembang }\end{array}$ & 23 Juni 2019 & $09: 00-16: 00$ & 7 jam \\
\hline $\begin{array}{c}\text { Terima Surat Tugas STEBIS untuk } \\
\text { melakukan pengabdian masyarakat } \\
\text { terhadap mahasiswa STEBIS IGM. }\end{array}$ & 26 Juni 2019 & $9: 00$ & 1 jam \\
\hline $\begin{array}{c}\text { Pembuatan materi ppt } \\
\text { Persiapan workshop }\end{array}$ & 05 Juli 2019 & $08.00-16.00$ & 24 jam \\
\hline $\begin{array}{c}\text { Pembuatan laporan akhir kegiatan } \\
\text { pengabdian masyarakat di STEBIS } \\
\text { IGM Palembang }\end{array}$ & 11-12 Juli 2019 & $13.00-17.00$ & 8 jam \\
\hline $\begin{array}{c}\text { Pengesahan laporan akhir kegiatan } \\
\text { pengabdian masyarakat di STEBIS } \\
\text { IGM Palembang dari pemimpin. }\end{array}$ & 15 Juli 2019 & $09.00-10.00$ & 1 jam \\
\hline \multicolumn{2}{|c|}{ Total Durasi Pelaksanaan pengabdian } & 44 jam \\
\hline
\end{tabular}

\subsection{Landasan Teori}

\subsubsection{Pemasaran}

Pemasaran adalah suatu proses sosial dan manajerial yang membuat individu dan kelompok memperoleh apa yang mereka butuhkan dan inginkan lewat penciptaan dan pertukaran timbal balik produk dan nilai dengan orang lain. (Irham Fahmi, 2015) Strategi pemasaran adalah pendekatan pokok yang akan digunakan oleh unit bisnis dalam mencapai sasaran yang telah ditetapkan lebih dulu, didalamnya tercantum keputusan-keputusan pokok mengenai target pasar, penepatan produk dipasar, bauran pemasaran, dan tingkat biaya pemaaran yang diperlukan. (Danang sunyoto, 2015)

Menurut prinsip syariah, kegiatan pemasaran harus dilandasi semangat beribadah kepada Tuhan Sang Maha Pencipta, berusaha semaksimal mungkin untuk kesejahteraan bersama, bukan untuk kepentingan golongan apalagi kepentingan sendiri. Pasar syariah sering kali dikatakan pasar yang bersifat emosional sementara pasar konvensional adalah pasar yang rasional ( Nur Rianto Al Arif, 2012). Maksud dari pernyataan tersebut adalah orang hanya tertarik untuk berbisnis pada pasar syariah hanyalah karena alasan emosional keagamaan semata dan bukan karena ingin mendapatkan keuntungan financial yang menrut sebagiab pihak dikatan sebagai sesuatu yang bersifat rasional. Sebaliknya pada pasar konvensional, orang ingin mendapatkan keuntungan finansial sebesarbesarnya tanpa terlau peduli apakah bisnis yang digelutinya mungkin menyimpang atau malah 
bertentangan dengan ajaran Islam atau apakah cara yang dipergunakan dalam memperoleh keuntungan tersebut menggunakan cara-cara yang kotor ataukah tidak.

\subsubsection{Komunikasi}

Komunikasi telah di definisikan oleh banyak pemikir dan pakar komunikasi sesuai dengan pendekatannya. Istilah komunikasi berasal dari kata common dalam bahasa Inggris atau commnunis dalam bahasa latin. Keduanya berarti bersamaan. Berkomunikasi merupakan kegiatan bersama antara orang untuk berbagai informasi, ide, keputusan tentang sesuatu. Dalam proses berbagai informasi terdapat tiga unsure pokok, yaitu komunikator, pesan dan komunikan. Secara umum bisa dipahami bahwa komunikasi adalah proses pengiriman dan penerimaan pesan dalam bentuk verbal maupun non-verbalyang disertai pemakaiaan terhadap pesan yang dikirim. (Sudaryono, 2016)

Pada umumnya, pengertian komunikasi ini paling tidak melibatkan dua orang atau lebih, dan proses pemindahan pesannya dapat dilakukan dengan menggunakan cara-cara berkomunikasi yang biasa dilakukan oleh seseorang melalui lisan, tulisan, maupun sinyal-sinyal nonverbal. Di dalam dunia praktis, Anda juga mengenal komunikasi antarpribadi (interpersonal communication) dan komunikasi lintas budaya (intercultural/cross-cultural communication), selain komunikasi bisnis (business communication). Komunikasi bisnis, komunikasi antarpribadi maupun komunikasi lintas budaya merupakan bentuk komunikasi yang masing-masing memiliki karakter yang berbeda dari yang lainnya.

Islam memandang komunikasi merupakan hal yang sangat penting, tetapi dalam melakukan komunikasi diperlukan adanya suatu keterbukaan, persamaan, persaudaraan, kejujuran dan kepercayaan.

\subsubsection{Minat Nasabah}

Minat menurut bahasa diartikan sebagai kecenderungan hati yang tinggi terhadap sesuatu, gairah, keinginan, dan suka terhadap sesuatu. Sedangkan berdasarkan definisi lain, minat adalah suatu rasa lebih suka dan rasa ketertarikan pada suatu hal atau aktivitas, tanpa ada yang menyuruh. Minat juga adalah kesadaran seseorang, bahwa suatu objek, seseorang. Suatu soal atau suatu situasi yang mengandung sangkut-paut dengan dirinya. (Suharsimi Arikunto, 2016)

Seseorang yang menaruh minat terhadap suatu objek akan merasakan adanya kebutuhan penting bagi kehidupannya, dan melakukan usaha-usaha yang teguh tanpa adanya paksaan dari orang lain. Untuk mendapatkan objek yang diminatinya tersebut, subjek harus mengidentifikasikan sejauh mana keuntungan dan kebutuhan yang diinginkan dari objek tersebut, bagaimana cara memenuhi keinginannya dan kemudian disikapi dengan membuat keputusan.

\section{TARGET DAN LUARAN}

\subsection{Target}

Target yang ingin dicapai dari kegiatan program pengabdian masyarakat di STEBIS IGM Palembang adalah sebagai berikut:

1. Dapat memahami tentang bagai mana cara menabung di BMT.

2. Mengetahui penerapan pemasaran dan komunikasi secara bersama-sama terhadap minat nasabah untuk menabung di BMT.

3. Kemudian dari pelatihan ini dapat meningkatkan minat para mahasiswa/i IGM untuk menabung di BMT.

\subsection{Luaran}

Target luaran dari workshop pemasaran dan komunikasi terhadap minat mahasiswa STEBIS IGM untuk menabung di BMT yaitu :

1. Para mahasiswa/i sangat antusias selama mengikuti sesi penyampaian materi dengan munculnya beberapa pertanyaan terkait menabung di BMT.

2. Para mahasiswa/i mengetahui bagaimana cara tahapan untuk menabung di BMT.

3. Laporan Akhir hasil pengabdian kepada masyarakat akan dipublikasikan pada Jurnal ABDIMAS UIGM.

\section{METODE PELAKSANAAN PENGABDIAN}


Kegiatan Pengabdian kepada masyarakat ini dilakukan dalam bentuk pelatihan mengenai cara menggunakan internet dan membuat bahan ajar berbasis multimedia, kegiatan pengabdian kepada masyarakat ini dilakukan selama 1 (satu) hari. Adapun kegiatannya sebagai berikut :

1. Nasabah BMT sebagai pengguna yang dapat meningkatkan sosialisasi tentang produk, mekanisme, seluk beluk tentang BMT kepada mahasiswa/i atau nasabah, dan diharapkan mereka bisa mengetahui kegiatan oprasional dan produk-produk yang ditawarkan BMT dengan baik serta memberikan informasi yang lengkap dan benar mengenai kegiatan usaha BMT kepada nasabah.

2. Penerimaan pendaftaran nasabah baru untuk di jadikan angkota BMT dengan mengguakan brosur atau data yang telah di siapkan oleh pihak BMT.

\subsection{Peserta}

Kegiatan Pengabdian kepada masyarakat ini di ikuti oleh para mahasiswa dan mahasiswi STEBIS IGM Palemang.

\subsection{Proses Kegiatan}

Proses kegiatan dilaksanakan dalam 1 (satu) kali pertemuan adalah sebagai berikut:

Tabel 3. Proses Kegiatan

\begin{tabular}{|c|c|c|}
\hline WAKTU & MATERI & FASILITATOR \\
\hline \multicolumn{3}{|c|}{ Rabu, 10 Juli 2019} \\
\hline 07:30 - 08:00 & Registrasi & Panitia dari Mahasiswa \\
\hline 08:00 - 08:15 & Pembukaan & Pemimpin atau ketua BMT \\
\hline $08: 15-08: 30$ & Pembukaan & $\begin{array}{c}\text { Ketua Pelaksanaan Pengabdian } \\
\text { Masyarakat dari STEBIS Indo } \\
\text { Global Mandiri }\end{array}$ \\
\hline $08: 30-11: 30$ & $\begin{array}{c}\text { Materi Pemasaran dan } \\
\text { Komunikasi Terhadap Minat } \\
\text { Nasabah Untuk Menabung di } \\
\text { Bmt } \\
\end{array}$ & $\begin{array}{c}\text { Narasumber : Nova Yanti Maleha, } \\
\text { S.E., M.M }\end{array}$ \\
\hline $13: 00-16: 30$ & Pengenalan Produk BMT & Narasumber : Fadilla, S.E.I.,MSi \\
\hline $16: 30-16: 35$ & Penutupan & $\begin{array}{l}\text { Ketua Pelaksanaan Pengabdian } \\
\text { Masyarakat }\end{array}$ \\
\hline
\end{tabular}

\section{HASIL DAN PEMBAHASAN}

Berdasarkan Surat Keputusan Mentri Dalam Negri Republik Indonesia c.q Direktur Jendral Pembangunan Daerah (Bangda), tanggal 14 April 1997 Nomor 538/PKK/IV/1997 tentang Status Badan Hukum untuk Lembaga Keuangan Syariah. Sebagai lembaga keuangan yang lahir dari sistem ekonomi Islam, BMT harus berlandasan pada tiga prinsip fundamental ajaran islam, yaitu tauhid (keesaan Tuhan), khalifah (perwakilan), dan 'adalah (keadilan).

Melalui kegiatan workshop ini diharapkan dapat meningkatkan keterampilan dan pengetahuan mahasiswa dan mahasiswi STEBIS IGM Palembang dalam hal pemasaran dan komunikasi terhadap untuk menabung di BMT.

\subsection{Penyampaian Materi Kegiatan}

Materi yang akan disampaikan dalam pengabdian kepada masyarakat ini akan dilaksanakan selama 1 (satu) hari yang dilaksanakan pada tanggal 02 Juli 2019 berupa penyampaian materi dan pengenalan dasar tentang Produk BMT. 

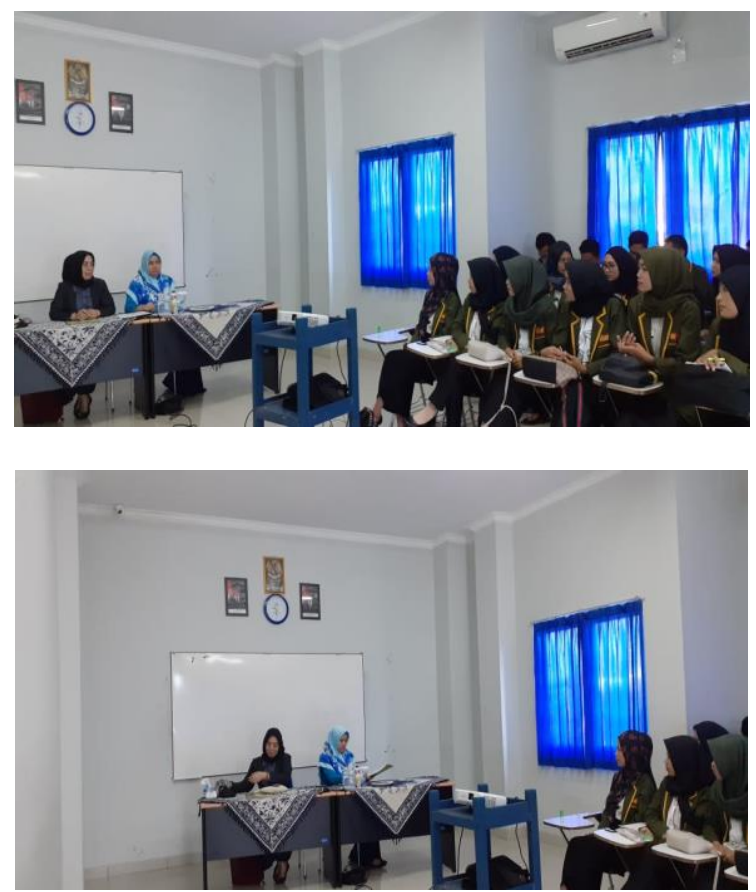

Gambar 4. Pembukaan Acara workshop BMT
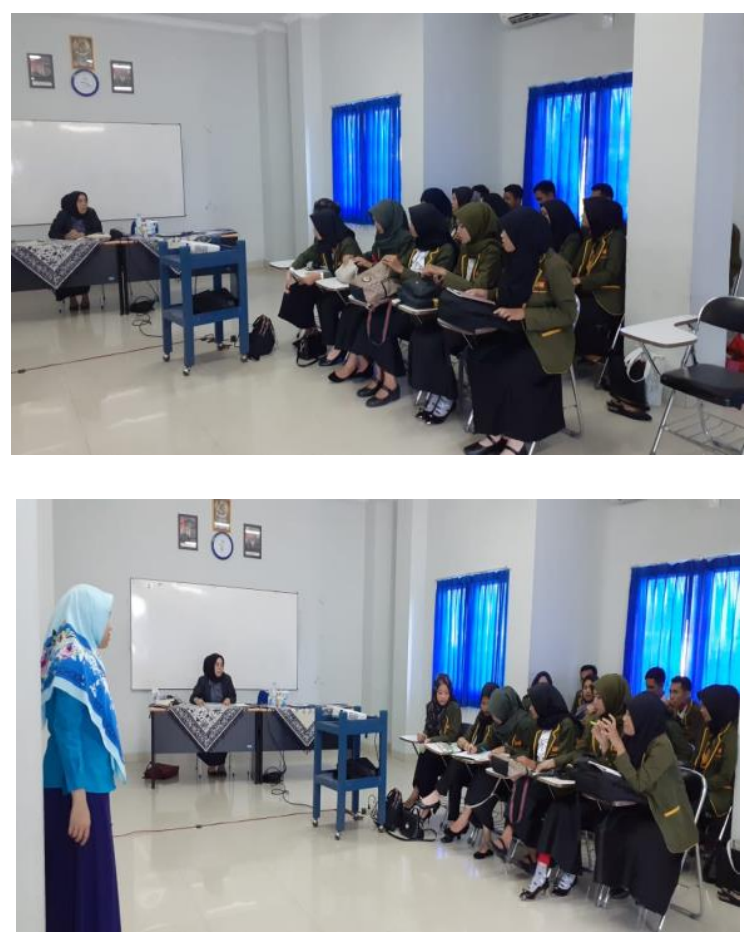

Gambar 5. Materi Pengenalan BMT

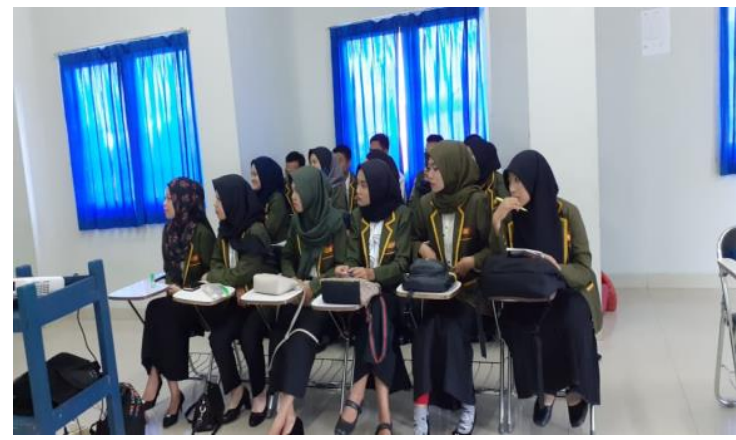

Gambar 6. Peserta kegiatan workshop BMT 


\section{KESIMPULAN}

Pelaksanaan kegiatan pengabdian pada masyarakat dengan tema "Sosialisasi Pemasaran Dan Komunikasi Terhadap Minat Nasabah Untuk Menabung Di BMT". Motifasi masyarakat muslim atau mahasiswa/i untuk terlibat dalam aktivitas berinvestasi di BMT harus terus ditingkatkan. Tingkat efektivitas keterlibatan masyarakat muslim dalam BMT tergantung pada sikap dan pola pikirmasyarakat muslim itu sendiri. Dan untuk mengubah sikap dan pola pikir masyarakat ini diperlukan waktu yang panjang disertai upaya-upaya yang lebih terstruktur dan berkesinambungan. Secara umum kegiatan pengabdian masyarakat ini telah berhasil dengan tercapainya luran yang diharapakan. Luaran tersebut berupa Pemasaran Dan Komunikasi Terhadap Minat Nasabah Untuk Menabung Di BMT yang dibuat oleh perserta pelatihan. Hasil evaluasi dari kegiatan workshop menunjukkan bahwa mahasiswa/i perserta workshop telah memahami sekilas bagaimana cara berinvestasi dan menabung BMT.

\section{DAFTAR PUSTAKA}

Danang Sunyoto, 2015, Strategi Pemasaran, (Yogyakarta: CAPS)

Gita Danupranata, 2015, Manajemen Perbankan Syariah, (Jakarta: Salemba Empat)

Irham Fahmi, Manjemen Perbankan Konvensional \&Syariah, (Jakarta: Mitra Wacana)

Fandiy Tjiptono, 2015, Strategi Pemasaran, (Yogyakarta: CV. ANDI OFFSET)

Muhammad Ridwan, 2014, Manajemen Baitul Maal Wa Tamwil (BMT), (Yogyakarta: UII Press)

Neni Sri Imaniyati, 2010, Aspek-Aspek Hukum BMT (Baitul Maal Wat Tamwil), (Bandung, PT. Citra Aditya Bakti)

Nur Rianto Al Arif, 2012, Dasar-Dasar Pemasaran Bank Syariah, (Bandung: Alfabeta)

Nur Rianto Al Arif, 2012, Dasar-Dasar Pemasaran Bank Syariah, (Bandung: Alfabeta)

Sudaryono, 2016, Manajemen Pemasaran, (Yogyakarta: CV. ANDI OFFSET)

Suharsimi Arikunto, 2016, Manajemen Penelitian, (Jakarta: PT RINEKA CIPTA) 